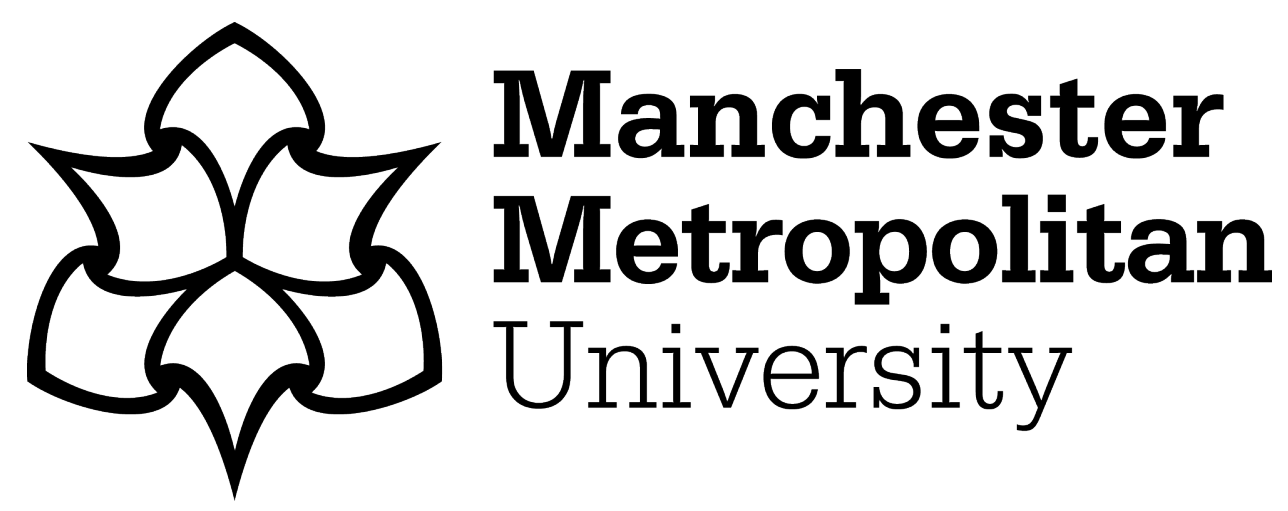

Lai, Yanqing ORCID logoORCID: https://orcid.org/0000-0001-9107-3464, Saridakis, George and Johnstone, Stewart (2016) Human resource practices, employee attitudes and small firm performance. International Small Business Journal, 35 (4). pp. 470-494. ISSN 0266-2426

Downloaded from: https://e-space.mmu.ac.uk/623800/

Version: Accepted Version

Publisher: SAGE Publications

DOI: https://doi.org/10.1177/0266242616637415

Please cite the published version 


\title{
Human resource practices, employee attitudes and small firm performance
}

\author{
Yanqing Lai \\ Edinburgh Napier University, UK
}

\section{George Saridakis}

Kingston University, UK

\section{Stewart Johnstone}

Newcastle University Business School, UK

\begin{abstract}
This article uses the matched employee-employer dataset from the Workplace Employment Relations Study of 20II (WERS20II) in Britain to empirically examine the direct relationship between human resource management (HRM) practices and small and medium-sized enterprise (SME) performance in the United Kingdom, as well as the potential moderating effect of organisational commitment/job satisfaction on the HRM-performance linkage. We find a positive and direct relationship between the use of certain formalised human resource (HR) practices and SME performance, measured by financial performance and labour productivity. More importantly, we find that the positive relationship between HR practices and financial performance varies between SMEs with high job satisfaction and low job satisfaction, and that the relationship is weakened in SMEs with high job satisfaction. The results suggest that certain HR policies and practices may improve small firm performance, especially within firms with low levels of commitment and satisfaction.
\end{abstract}

\section{Keywords}

employee attitudes, human resource practices, microeconometrics, small firm performance, WERS

\section{Introduction}

Research concerning the links between human resource management (HRM) and performance has flourished over the past 20 years and is central to the field of strategic human resource management 
(SHRM) (Guest et al., 2013). In the last decade, there has also been growing interest in the HRMperformance nexus in small firms (Allen et al., 2013; Michie and Sheehan, 2008; Sheehan, 2014). Reflecting the extensive evidence reported in the large business context (Guest et al., 2013), studies suggest that the use of certain HRM systems are significantly and positively related to different indicators of small-business performance, such as firm profitability and labour productivity (Nguyen and Bryant, 2004; Sels et al., 2006). The findings offer some support for the universalistic perspective of SHRM which posits that certain HRM practices, or so-called 'best practices', are positively associated with firm performance irrespective of context (Huselid, 1995).

However, the precise nature of the links between HRM and performance remains contested, and our understanding of how and why human resource (HR) practices affect performance is still limited (Guest, 2011). In response, the HRM literature has called for a greater understanding of the intermediating mechanisms through which HR practices are linked to firm performance (Becker and Huselid, 2006; Jiang et al., 2013; Paauwe, 2009). In order to unravel this so-called 'black box', and to explore the intricate pathways leading from HRM practices to organisational performance, various theories and conceptual frameworks have been applied. The most popular is perhaps the resource-based view (RBV) which stresses the importance of the internal pool of human resources and has been described as 'the guiding paradigm on which virtually all strategic HRM research is based' (Allen and Wright, 2007: 90). Other frameworks include intellectual capital (IC), the behavioural perspective, the symbolic view of firms, attribution approaches and social exchange theory (SET) (Jiang et al., 2013; Lepak et al., 2006). A social exchange framework and quantitative methodologies at the micro-level have also been adopted, suggesting the HRM-performance relationship may be mediated by attitudinal variables (Truss et al., 2013). The orthodoxy within this stream of research is that sophisticated and formalised HRM systems (sometimes referred to as high commitment or high-performance work practices) can create high levels of organisational commitment and job satisfaction, and in turn superior job and firm performance (Conway and Monks, 2009; Snape and Redman, 2010). In terms of the number of HR practices, a common view is that 'more is better' (De Winne and Sels, 2013; Guest and Conway, 2011). Yet despite extensive research, the precise nature of the links between HRM and performance remains both contested and controversial. While Kaufman (2010) has described the area as 'the most exciting and fastest growing area of research in HRM' (p. 286), critical HRM scholars have expressed fundamental concerns regarding the value of the HRM-performance project (Delbridge and Keenoy, 2011; Thompson and Harley, 2007). Others remain more sympathetic to the potential of such analysis, but have encouraged researchers to address the various methodological limitations and provided useful suggestions for future research (Guest, 2011; Paauwe et al., 2013). It is some of these methodological challenges that we try to address.

An important limitation is the observation that most studies exploring the 'black box' between HRM and organisational performance have been conducted in large organisations (Subramony, 2009), and considerably less research has focused on small businesses. The focus of our paper is, therefore, the extent to which large firm-oriented HRM-performance models are relevant to the study of small organisations. Commentators note how smaller businesses are distinctive from their larger counterparts, with prototypical characteristics including more flexible organisational structures and a more informal and fluid approach to the management of employment relations (Marlow, 2005). Our specific aims are twofold. First, drawing on the three dominant theories of SHRM (universalistic, contingency and configurational perspectives), and focusing on the macro-level, we examine whether there is a direct or linear relationship between the use of formalised HR practices and firm performance in small organisations. Second, situated within SET, the ability-motivation-opportunity (AMO) framework and contingency theory, analysis is also undertaken at the micro-level by exploring the intermediating effect of organisational commitment and job 
satisfaction on the HRM-performance linkage within the small-business context. We also examine whether the level of firm performance (financial performance and labour productivity) varies between small and medium-sized enterprises (SMEs) with high organisational commitment/job satisfaction compared to those with low organisational commitment/job satisfaction. To do this, we use a large matched employee-employer dataset from the British Workplace Employment Relations Study of 2011 (WERS2011).

The article is structured as follows. The first section discusses the relationship between employee attitudes, HR policies and firm performance in small firms and outlines a series of hypotheses. More specifically, the universal perspective of SHRM is applied to examine the direct relationship between HRM practices and firm performance in SMEs (H1), while the SET and contingency perspectives of SHRM are used to investigate the intermediating effect of job satisfaction/organisational commitment on HRM-performance linkage ( $\mathrm{H} 2$ and $\mathrm{H} 3)$. We then describe the dataset and the key variables used in the analysis. The next sections presents the estimation results, followed by a discussion of the empirical findings. The final section considers the implications of our findings and identifies potential avenues for future research.

\section{Background and hypotheses derivation}

\section{HRM in SMES}

Small businesses are not simply scale-downed versions of large firms, so we cannot simply assume that the plethora of management concepts and theories associated with large organisations are necessarily applicable to small businesses (Westhead and Storey, 1996). This includes approaches to the management of human resources and employment relations. However, reflecting the need to explore actual as well as intended HR practices (Boxall and Purcell, 2011; Wright and Nishii, 2013), we are not just interested in which HR policies and practices are adopted or espoused, but also how they are adopted and implemented. Of particular interest is the formality of HRM, defined as the extent to which HR policies and practices are documented, systemised, institutionalised and integrated into the firm (Nguyen and Bryant, 2004), with the highest indicator of HR formality being the presence of a specialist HR professional to manage HR issues (Singh and Vohra, 2009). This is important as in large firms key HR activities - such as recruiting, selecting, developing, utilising, rewarding and motivating employees - are usually supported by an HR department, or at least an HR specialist. Small firms, in contrast, are often reported to lack sophisticated and formalised HR practices and rarely have HR professionals and experts (Wapshott and Mallett, 2015). Instead, HR issues may remain the domain of organisational leaders, especially founders and owners, or may be delegated to other non-specialist staff as part of their wider managerial remit (Marlow et al., 2010). It is interesting to note that over half of British employees (55\%) are employed in small workplaces with no official HR specialist (Van Wanrooy et al., 2013), and the presence or absence of an HR expert largely depends on workplace size.

In addition to and perhaps even because of these different structures, working practices and relationships in smaller firms are often governed by informal rules, unwritten customs and tacit understandings. Regular employer-employee interactions are central to the governance of the employment relationship (Kitching and Marlow, 2013), rather than the formal rules, policies documents, written agreements and staff handbooks commonly associated with large firms. Singh and Vohra (2009) suggest that explicit, written HR policies and procedures are present to varying degrees in small firms, but that generally HR activities in SMEs are informal, reactive and have a short-term outlook (De Kok et al., 2002; De Kok and Uhlaner, 2001). Employee performance might be managed more directly and informally (Cassell et al., 2002), there may be no formal basis 
for the review and negotiation of pay and reward (Wapshott and Mallett, 2015) and training might be limited to meeting immediate expediencies rather than long-term HR development strategies (Marlow, 2005). As HR formality is strongly associated with the size of an organisation, the notion of informality is central to our understanding of HR in small businesses, and can potentially be explained by contextual factors such the absence of resources and professional knowledge, management expertise or preference, and social and spatial proximity (Marlow, 2005; Marlow et al., 2010). The normative thrust of much SHRM research, such as the need for a combination of carefully designed HR practices and policies geared towards improving organisational effectives and performance (Boselie et al., 2005), is therefore more questionable in the context of SMEs.

\section{Examining the HRM-performance relationship at the macro-level}

Early studies concerning the relationship between HRM and performance tended to focus on the macro- or organisational level (Guest, 2011), and the specialist sub-field of SHRM has evolved from this research tradition. While there is now considerable evidence to support the notion that certain HR practices are associated with strong organisational performance (Paauwe and Boselie, 2005; Wall and Wood, 2005), the precise nature of such links remains unclear, or as Guest (2011) notes, 'we are more knowledgeable but not much wiser' (p. 3).

Nevertheless, three perspectives now dominate SHRM theorising: the universalistic, contingency and configurational perspectives (Delery and Doty, 1996). The central proposition of the universalistic perspective is that a particular set of HRM policies and practices is positively linked to organisational performance irrespective of context (Savaneviciene and Stankeviciute, 2012). This position is normally associated with the influential works of scholars including Huselid (1995) and Pfeffer (1998). Some suggest that the positive relationships between different best practices are additive: the more policies or practices used, the better business performance will be, while others suggest a more multiplicative effect associated with particular 'bundles' (Becker and Gerhart, 1996; MacDuffie, 1995). The contingency theorists, on the other hand, argue that an effective HRM strategy can depend on the specific organisational or environmental context (Chuang and Huang, 2005). From this perspective, the relationship between HRM and firm performance may be conditional upon a range of variables (Combs et al., 2006; Sheehan, 2014), including organisational strategy, external environment, country, sector and employee groups. The contingency perspective is more complex because of implied interactions rather than the simple linear relationships which characterise the universalistic perspective (Delery and Doty, 1996). The prescriptions are also less clear given the emphasis on 'matching' HR practices within a complex and dynamic context. A third view - the configurational approach - combines elements of both the best practice and contingent approaches, and proposes that effective organisations must develop a coherent 'HR system' that achieves both horizontal and vertical fit, with the potential to create 'synergistic' effects (Guest, 2011). Horizontal fit refers to the internal consistency of the organisation's HR policies, while vertical fit concerns the congruence of the HRM system with the organisational context. Again, while configurational models potentially offer more robust insights into the dynamics of an HR system, it can also be more difficult to interpret and apply. This perhaps explains partly the enduring allure and dominance of more simplistic but easily digestible, best practice models. Yet despite important differences between the three perspectives outlined above, they share a common assumption that HR positively affects organisational performance and often imply that in terms of HR practices, 'more is better' (De Winne and Sels, 2013; Kaufman, 2015). The main focus is also the examination of HRM at the macro-level, and the potential links with a fairly narrow, business-focused definition of 'performance' (Paauwe, 2009). 
Although most of the above debates have occurred in the context of large firms, there has been increasing interest in exploring the relationship between HRM practices and firm performance in the small-business context. This line of research either stresses the significance and/or the success of HR policies and practices (Cassell et al., 2002; Rowden, 2002), or statistically tests whether multiple or individual HRM policies (in particular, employee training and development) are significantly related to organisational performance (Drummond and Stone, 2007; Sels et al., 2006). In common with large-firm studies, a positive link between the use of HR policies and practices and small-business performance has been identified in the majority of empirical studies. For example, Way (2002) suggests that high-performance work systems are negatively associated with workforce turnover, and positively related to labour productivity among small US firms. Sheehan's (2014) study of British small firms also shows a significant, simultaneous and longitudinal relationship between the use of formal HR practices and different indicators of firm performance. This longitudinal study also controls for previous performance in the estimation, therefore addressing concerns regarding the potential for reverse causality in the HRM-performance relationship, an issue which has been under-researched in the HRM literature (Razouk, 2011). While acknowledging that the majority of these studies are exploratory and descriptive in nature (De Kok, 2003), existing studies of HRM and performance within the small-business sector tend to broadly reflect a best practice view of SHRM, confirming a positive and direct association between certain HRM practices and firm performance, seemingly irrespective of other contextual variables. Therefore, on balance, we hypothesise that

\section{H1. Formalised HR practices are positively and directly related to small firm performance.}

\section{Examining the HRM-performance relationship at the micro-level}

SET. While several studies of HR and performance in the small-business context examine the potential impact of HRM at the macro-level, less is known about employee perceptions of - and responses to - HR practices. This is perhaps surprising given HRM is concerned with the effective management of people, and recurrent calls from HR scholars to pay greater attention to employee views in HRM research (Guest, 1999, 2002). In understanding employee behaviour and responses, the HR literature has increasingly adopted insights from SET. In simple terms, social exchange is the most basic form of exchange (Blau, 1964) and is mainly based on the norm of reciprocity. It posits that where one party is offered a rewarding activity, gift or favour by another, party one will receive an obligation to reciprocate party two's favour in a similar and timely fashion and vice versa. As each party regularly reciprocates and discharges their obligations, they prove themselves trustworthy and committed to each other. Notions of social exchange have a long pedigree in the field of industrial relations (IR) and pluralist theories of the employment relationship, and the mainstream HRM literature has also increasingly adopted a social exchange framework in the development of concepts such as the psychological contract (Blyton et al., 2008; Cullinane and Dundon, 2006). Central to both interpretations, however, is the view that employment is more than a straightforward economic or legal relationship but also has complex and dynamic social, psychological and political dimensions.

From an HRM perspective, the key argument is that the interaction of HRM practices at the organisational level, and employee attitudes and behaviours at the individual level, is central to our understanding of the links between HR and performance (Paauwe, 2009; Truss et al., 2013). Current concerns with raising 'employee engagement' illustrate this continued interest (Purcell, 2014). As IR and pluralist/critical HRM scholars have long argued, employees are not simply passive recipients of $\mathrm{HR}$ practices or management interventions despite the unitarist assumptions of 
much HRM writing (Legge, 2004). For HRM, this highlights the importance of understanding mediating mechanisms, such as employee attitudes and behaviours, and it is organisational commitment and job satisfaction which have attracted the greatest interest (Savaneviciene and Stankeviciute, 2012).

Mowday et al. $(1979,1982)$ define organisational commitment as 'the relative strength of an individual's identification with and involvement in a particular organisation'. It is further characterised by three factors: (1) a strong belief in, and acceptance of, the organisation's goals and values; (2) a willingness to exert considerable effort on behalf of the organisation; and (3) a strong desire to remain in the organisation. Accordingly, high levels of organisational commitment concern strong and positive feelings towards an organisation and its values, as well as congruence between the beliefs and values of employers and employees (Swailes, 2002). Job satisfaction, on the other hand, is defined as a pleasurable emotional state that results from the valuation of one's work (Locke, 1976). It is commonly regarded as a constellation of employee feelings about their work and the attitudes towards various aspects or facets of the job. It is argued that committed and satisfied workers, who engage in collaborative efforts in support of organisational goals, can create a work environment that encourages employees to reason and behave ethically. This occurs through social processes and workplace norms, as well as helping firms experience additional benefits through positive interactions among employees (O'Fallon and Butterfield, 2005; Valentine et al., 2011). These positive interpersonal norms are believed to be positively related to the productivity of a group or organisational unit (Guzzo and Shea, 1992), ultimately resulting in superior firm performance.

Generally, employees are more likely to reciprocate through positive work attitudes and behaviours, and to exert higher levels of effort in support of the goals and strategies of the organisation, if managerial decisions have a positive effect on employee physical and psychological needs (McClean and Collins, 2011). Van Knippenberg and Sleebos (2006) argue that job satisfaction and organisational commitment are social exchange outcomes, and reflect perceptions of the quality of the exchange. According to this line of reasoning, the use of planned HR activities and interventions that attempt to shape employee perceptions of the nature of their employing organisation's HRM strategy, represents a desire on the part of the employer to develop and support high levels of job satisfaction and commitment (Gould-Williams, 2007). In return, employees are expected to be more willing to reciprocate by deploying their ability, motivation and participation in the pursuit of firm goals (Allen et al., 2013). Indeed, HR scholars have shown that high levels of employee commitment and job satisfaction can be fostered by implementing certain HRM practices. The presence of effective recruitment and selection practices, training opportunities, career and promotional opportunities, grievance solution mechanisms, appropriate employee responsibility, autonomy, participation and performance appraisal are all found to be positively related to organisational commitment and job satisfaction (Fiorito et al., 2007; Gould-Williams and Davis, 2005; Kuvaas, 2008).

In SHRM, the notion of social exchange is also central to the influential 'AMO' framework proposed by Appelbaum et al. (2000). The model considers the potential for HR mechanisms to contribute to the knowledge, skills and abilities of employees (dimension 'A' for ability); employee motivation to perform as desired and to exhibit discretionary behaviour (' $\mathrm{M}$ ' for motivation); and work systems which encourage participation in decision-making (dimension ' $\mathrm{O}$ ' for opportunity). These three dimensions are believed to tap into the discretionary effort of employees, enhancing the perceived trustworthiness of the organisation and shaping individual and aggregate employee characteristics and attitudinal behaviours. Again, this is ultimately believed to be associated with firm success (Harney and Jordan, 2008; Searle et al., 2011). However, Jiang et al. (2012) also find differential effects of the three dimensions, and challenge the assumption that all HR practices in an HR system function in the same way. This may be particularly true in the small-business 
context, and it is possible that the relationship between each dimension of the AMO framework and employee/organisational outcomes may vary from large firms.

SET in SME context. As Allen et al. (2013) note, existing studies of the so-called 'black box' in SHRM are predominantly conducted in large firms, with fewer studies in the small-business context (for exceptions, see Allen et al., 2013; Sels et al., 2006). Yet HRM researchers have highlighted how we cannot simply generalise from large organisations to small organisations given the distinctive processes and structures that characterise small businesses (Cassell et al., 2002; Marchington et al., 2003). The effectiveness of adopting HR mechanisms depends not just on understanding the composition of the HRM system, but equally an appreciation of broader structural and contextual factors such as firm size (Drummond and Stone, 2007; Nadin and Cassell, 2007), as well as how practices are implemented and enacted.

A context of relative resource poverty, great external uncertainty and short-term time horizons often means the management style in SMEs is more informal (Marlow et al., 2010). From an HR perspective, this does not necessarily mean small firms are less effective or less efficient; informality might actually foster job satisfaction and employee commitment. Workers in small firms may also be able to take advantage of personal ties with employers to acquire pay and non-pay benefits beyond those formally specified, and benefit from greater recognition than is available in large firms (Kitching and Marlow, 2013). Accordingly, formal HR practices enacted to achieve high levels of employee commitment and job satisfaction in small organisations may not resemble those associated within the AMO framework in large organisations. They may even be ineffective because of the particular characteristics of small organisations (Sheehan, 2014), such as a less hierarchical structure and greater emphasis on informality (Jack et al., 2006). Cassell et al. (2002) and Artz (2008) find that the use of formal appraisal systems by SMEs is rare, and in some cases, specific HR mechanisms seem to do more harm than good. This is possibly because in a small businesses, employee performance can be observed more easily without formal performance management systems; indeed, formal appraisal practices might be interpreted as monitoring and controlling mechanisms rather than motivating (Marsden et al., 2000). Studies have also reported that employees in small firms experience better intrinsic job quality, emphasising flexibility and informality with regard to information sharing, communication and involvement in decision-making, than those in larger firms (MacDermid et al., 2001; Storey et al., 2010; Tsai et al., 2007). Arguably, informal empowerment-enhancing HR practices are more suited to small businesses to develop and maintain job satisfaction and organisational commitment, suggesting that an increase in formalisation in HRM may not be welcomed.

On the other hand, the limitations of informality may become apparent in some key HR areas including employee training and development (Hoque and Bacon, 2006; Saridakis et al., 2008). Ability-enhancing HR practices such as training can play an important role in employee skills formation and lead to greater career and promotion opportunities. However, evidence also shows that employees in small businesses are less likely to have access to structured training provision than employees of large firms (Storey, 2004). Limited training and development opportunities might mean employees in small firms are less likely to be committed to the organisation or satisfied with their job, although it is also possible that some small firms may be willing to invest in the development of their employees in order to retain competitiveness and reduce labour turnover. Whether formalisation of certain HR practices is deemed necessary or desirable would seem to depend on specific contextual factors.

Empirical evidence regarding these issues has been mixed, with small-business employees regularly reporting higher levels of organisational commitment and job satisfaction (De Clercq and Belausteguigoitia Rius, 2007; Storey et al., 2010), while other studies report a variety of poor HR 
outcomes in SMEs including job insecurity, skill shortages, lower pay and limited promotion opportunities (Hoque and Bacon, 2006). A recent analysis of SMEs in the United Kingdom (Storey et al., 2010) suggests that formalised HR practices and policies lead to a significant decrease in job satisfaction, especially in SMEs (Forth et al., 2006; McCartney and Wilmott, 2009). Similarly, De Clercq and Belausteguigoitia Rius (2007) suggest that the negative association between organisational commitment and firm size can be partially explained by management formality. They find that the high levels of organisational commitment and job satisfaction, observed in small organisations, are related to the intrinsic job qualities associated with informality, such as close working relationships, flexible working patterns, negotiable work responsibilities and more opportunities to participate. Kaman et al. (2001) find that the motivation-enhancing and opportunity-to-participateenhancing HR practices that comprise information sharing, open channels of communication, extensive training, teamwork, incentive-based compensation and flexibility in scheduling are not necessarily associated with a large workforce size. Small businesses can also create a greater level of employee commitment and job satisfaction through informal mechanisms, and the adoption of informal and ad hoc work practices that create strong reciprocity. Hence, formalisation in HRM might be deemed unnecessary and undesirable in SMEs, with high employee job satisfaction and organisational commitment derived in the context of formality.

On the other hand, for underperforming small organisations with low employee commitment or job satisfaction, formalisation of HRM can be viewed as a means to improve employee perception of fairness, trust and procedural justice (Saridakis et al., 2013). Formalised HR policies and practices may have a signalling effect to employees that organisations have a desire to commit to them, are willing to invest in the workforce and care about employee welfare and development (Allen et al., 2013; Snape and Redman, 2010). This may stimulate positive behaviours, potentially increasing individual efforts and performance in underperforming small firms. Increased formality may also directly increase organisational efficiency by increasing managerial control (Patel and Cardon, 2010).

Overall, the above theoretical discussion and mixed empirical evidence suggest that the positive relationship between formalised HR practices and small-business firm performance may be contingent on the levels of employee organisational commitment and job satisfaction that is developed within the context of informality. In order to advance understanding, we use a large matched employer-employee dataset (in this case, WERS2011 UK) which enables us to separate employer and employee effects, and to examine the roles of both firms and workers in explaining the observed differences in the HRM-performance relationship. We therefore hypothesise that

H2. The positive relationship between formalised HR practices and financial performance in small firms $(2 a)$ is moderated by high organisational commitment and $(2 b)$ by high job satisfaction.

H3. The positive relationship between formalised HR practices and labour productivity in small firms is $(3 a)$ moderated by high organisational commitment and $(3 b)$ by high job satisfaction.

\section{Data}

\section{Dataset description}

The present study uses data from the WERS2011. This is the sixth in a series of publicly funded and nationally representative cross-section of surveys based on a stratified random sample of 
British establishments (only those with five or more employees are included), and includes a sample of managers and employees at those establishments (for more detailed discussion, see Deepchand et al., 2013). The WERS data are composed of four sections, ${ }^{1}$ and this study focuses on two: Management Questionnaire and Employee Questionnaire. The Management Questionnaire consists of face-to-face interviews with the senior manager with responsibility for employment relations in each establishment surveyed $(n=2680$; response rate $=46 \%)$. The Employee Questionnaire is completed by a random sample of up to 25 employees in each establishment surveyed by answering a self-completion questionnaire $(n=21,981$; response rate $=54 \%)$.

\section{Measures}

Firm size. Our construct for firm size is drawn from the Management Questionnaire and is consistent with the standard European definition: firms that have fewer than 50 employees are defined as small (5-49 employees) and those with up to 249 employees comprise SMEs (50-249 employees). The WERS data include information on workplace size, identify workplaces within both singlesite and multi-site enterprises and ask for the total number of employees in the organisation of which the workplace is part. In the present study, we focus on the firm size as a whole: a sample of 3488 employees from 448 privately owned SMEs in the United Kingdom. ${ }^{2}$

Organisational performance. Two indicators of organisational performance are utilised: financial performance and labour productivity. These measures are drawn from the Management Questionnaire. In particular, managers are asked to provide answers to the following questions: 'Compared with other establishments in the same industry, how would you assess financial performance?' and 'Compared with other establishments in the same industry, how would you assess labour productivity?' Reponses to these questions are measured on a 5-point Likert scale ${ }^{3}$ and coded as 5 ' a lot better than average', 4 'better than average', 3 'about average', 2 'below average' or 1 'a lot below average'. As the series relies on respondent interpretations of performance, we acknowledge the limitations of subjective measures of firm performance. However, the existing literature has also suggested that subjective measures are appropriate proxies to evaluate firm performance in the analysis of HRM and organisational success (Den Hartog and Verburg, 2004; Ferguson and Reio, 2010). Such measures have been used repeatedly in the highly reputable WERS series in Britain (Brown et al., 2010; Saridakis et al., 2013). Wall and Wood (2005) argue this method may lead to a 'common method variance' issue and create spurious relationships, although as Wall et al. (2004) also note, such common source self-report performance data may not be as biased as one might expect. Comparing the subjective and objective measures of firm performance in the WERS2004, Forth and McNabb (2008) find strong correlations between the measures, suggesting subjective measures of financial performance and labour productivity can be considered as appropriate alternatives to objective measures.

Organisational commitment. Organisational commitment was constructed and captured by using a three-item scale (see also Brown et al., 2010; Forth et al., 2006). These statements are drawn from the Employee Questionnaire: (1) 'I share many of the values of my organization', (2) 'I feel loyal to my organization' and (3) 'I am proud to tell who I work for'. To assess the degree of agreement, responses were evaluated on a 5-point Likert scale: 'strongly agree' $=5$, 'agree' $=4$, 'neither agree nor disagree' $=3$, 'disagree' $=2$ or 'strongly disagree' $=1$. An overall measure of employee commitment was created after computing Cronbach's $\alpha(0.86)$, suggesting great internal consistency and reliability. 
Job satisfaction. Job satisfaction is constructed in accordance with Kersley et al.'s (2006) study and is also drawn from the Employee Questionnaire. Specifically, employees were asked to what extent they are satisfied with eight aspects of their job. The eight items included 'the sense of achievement', 'scope of using own initiative', 'amount of influence over the job', 'training received', 'the opportunity to develop your skills in your job', 'amount of pay received', 'job security' and 'amount of involvement in decision-making at the workplace'. The responses are evaluated in a similar way to the measurement of organisational commitment (a 5-point Likert scale). An overall index was created after estimating Cronbach's $\alpha$ (0.89), and we distinguished between firms with high/low employee commitment and high/low job satisfaction. Firms with mean scores above 3.5 for overall employee commitment or job satisfaction are interpreted as firms with high employee commitment or job satisfaction. ${ }^{4}$ Consistent with prior studies (Forth et al., 2006; McCartney and Wilmott, 2009), the weighted average results (see Table 5 in Appendix 1) show that job satisfaction and organisational commitment decrease as firm size increases, suggesting a negative association between the two variables.

$H R$ practices. Management formality is proxied by $12 \mathrm{HR}$ policies and practices extracted from the Management Questionnaire. However, there is no consensus regarding which employment practices constitute a comprehensive or essential 'HRM checklist' (Boselie et al., 2005). As a result, following the work of Saridakis et al. (2013) and Storey et al. (2010), we investigate the set of HR practices $^{5}$ reflecting management formality and formal procedures in key HR areas such as employee development, performance management and reward, grievance and dismissal procedure and communication. We then calculate the Cronbach's $\alpha(0.74)$ and an overall scale ranging from 0 to 1 is constructed. As expected, there is a significant positive relationship between the use of formalised HR practices and firm size (see weighted proportion results in Table 6 in Appendix 1). In combination with the work of Storey et al. (2010) and the outcomes presented in Table 5, our results suggest that both organisational commitment and job satisfaction decrease with management formality.

\section{Statistical techniques: ordered probit regression}

The correlation of the primary explanatory and dependent variables is presented in Table 1 . We then use ordered probit regression to examine the potential relationship between formalised HR practices, employee attitudes and small-business performance. Ordered probit regression is a statistical technique used in the cases of more than two outcomes of an ordinal observed variable. The model is estimated by maximum likelihood and regresses a function of the probability that a case falls in a certain outcome category of the outcome variable on a set of independent variables (Stock and Watson, 2007). We also control for a wide range of demographic characteristics that are consistent with prior studies (Brown et al., 2010; Sels et al., 2006; Sheehan, 2014). A full list of the descriptive statistics of these controlled variables is presented in Table 7 in Appendix 1.

\section{Empirical results}

Our analysis starts with the full SME sample and then moves on to two sub-samples: small firms ( $n=5-49$ employees) and medium-sized firms ( $n=50-249$ employees). This allows us to examine whether the relationship between HR practices and firm performance differs within the SME population. We start the analysis by comparing the weighted averages ${ }^{6}$ of firm performance in each size band of SMEs with low and high level of HR formality. We then estimate an ordered probit 
Table I. Correlation between explanatory and dependent variables.

\begin{tabular}{llllll}
\hline & $\begin{array}{l}\text { Organisational } \\
\text { commitment }\end{array}$ & $\begin{array}{l}\text { Job } \\
\text { satisfaction }\end{array}$ & Formality & $\begin{array}{l}\text { Financial } \\
\text { performance }\end{array}$ & $\begin{array}{l}\text { Labour } \\
\text { productivity }\end{array}$ \\
\hline Organisational commitment & 1.000 & & & & \\
Job satisfaction & 0.465 & 1.000 & & & \\
Formality & 0.058 & -0.035 & 1.000 & & \\
Financial performance & 0.081 & 0.065 & 0.099 & 1.000 & 1.000 \\
Labour productivity & 0.049 & 0.058 & 0.132 & 0.448 & 1.000 \\
\hline
\end{tabular}

$n_{\text {SMEs }}=448 ; n_{\text {small firms }}=296 ; n_{\text {medium-sized firms }}=152$.

Table 2. Averages of small-business firm performance based on high and low presence of formalised HR practices (means, weighted estimates).

\begin{tabular}{|c|c|c|c|c|c|c|}
\hline \multirow{2}{*}{$\begin{array}{l}\text { Firm performance } \\
\text { Sample }\end{array}$} & \multicolumn{3}{|c|}{ Financial performance } & \multicolumn{3}{|c|}{ Labour productivity } \\
\hline & SMEs & $\begin{array}{l}\text { Small-sized } \\
\text { firms }\end{array}$ & $\begin{array}{l}\text { Medium-sized } \\
\text { firms }\end{array}$ & SMEs & $\begin{array}{l}\text { Small-sized } \\
\text { firms }\end{array}$ & $\begin{array}{l}\text { Medium-sized } \\
\text { firms }\end{array}$ \\
\hline \multicolumn{7}{|c|}{ Formalised HR practices } \\
\hline \multirow[t]{2}{*}{ Low } & 3.302 & 3.305 & 3.000 & 3.546 & 3.546 & 3.512 \\
\hline & $\overline{0.107}$ & $\overline{0.108}$ & 0.000 & 0.090 & 0.091 & 0.355 \\
\hline \multirow[t]{2}{*}{ High } & 3.536 & 3.52 & 3.555 & 3.664 & 3.642 & 3.691 \\
\hline & $\overline{0.058}$ & $\overline{0.061}$ & 0.105 & 0.052 & 0.056 & 0.093 \\
\hline Obs. & 3,488 & 1,909 & $\mathrm{I}, 579$ & 3,488 & 1,909 & 1,579 \\
\hline
\end{tabular}

HR: human resource.

$n_{\text {SMEs }}=448 ; n_{\text {small firms }}=296 ; n_{\text {medium-sized firms }}=152$.

The values in italic are standard errors.

The overall measure of HR formality is a continuous variable, ranging from 0 to I (see Section 'Measures'). In this table, in order to differentiate low HR formality to high one, responses are given value of unity if scores are between 0.5 and I.0 (cf. high HR formality) and zero if scores are between 0 and 0.49 (cf. low HR formality).

We test the hypothesis of the averages of firm performance within SMEs, small firms and medium-sized firms with high and low HR formality, respectively. Bold and underline suggest that the difference is statistically significant at I\% and $10 \%$ level, respectively.

We estimate locally weighted scatterplot smoothing (lowess) to visually assess the relationship between firm performance and formalised HR practices, since we use a large matched employee-employer dataset. Using the bandwidth of 0.8 , the results suggest a non-linear but positive relationship between formalised HR practices and firm performance.

regression model $^{7}$ to test the direct association between HR formality and performance, taking a wide range of workforce and organisational characteristics into consideration.

$\mathrm{H} 1$ proposes a positive and direct relationship between HRM and performance. Table 2 presents the weighted averages of firm performance for each size band of SMEs. Small firms that exhibit higher levels of formality are more likely to report better than average financial performance and labour productivity than those exhibiting a low presence of formal HR policies and practices. Similar findings are also applicable to medium-sized firms and SMEs as a whole. These results suggest that formalised HR mechanisms are positively associated with financial performance and labour productivity in SMEs as a whole. This is also true when small and medium-sized firms are separated from each other. Table 3 shows the coefficient results for the ordered probit regression model. Formalised HR practices are positively and statistically significantly related to financial performance and labour productivity in SMEs, as well as SMEs when small firms are separated 
Table 3. Ordered probit estimation of small-business firm performance: the direct effect of formalised HR practices.

\begin{tabular}{|c|c|c|c|c|c|c|}
\hline \multirow{2}{*}{$\frac{\text { Firm performance }}{\text { Sample }}$} & \multicolumn{3}{|c|}{ Financial performance } & \multicolumn{3}{|c|}{ Labour productivity } \\
\hline & SMEs & $\begin{array}{l}\text { Small-sized } \\
\text { firms }\end{array}$ & $\begin{array}{l}\text { Medium-sized } \\
\text { firms }\end{array}$ & All SMEs & $\begin{array}{l}\text { Small-sized } \\
\text { firms }\end{array}$ & $\begin{array}{l}\text { Medium-sized } \\
\text { firms }\end{array}$ \\
\hline $\begin{array}{l}\text { Ordered probit } \\
\text { regression }\end{array}$ & Coefficient & Coefficient & Coefficient & Coefficient & Coefficient & Coefficient \\
\hline \multirow[t]{2}{*}{ HRM formality } & $1.085^{*}$ & $1.220 *$ & $1.108 *$ & $0.942 *$ & $1.092 *$ & $0.636 *$ \\
\hline & $0.1 / 8$ & 0.159 & 0.259 & 0.121 & 0.161 & 0.275 \\
\hline Controls & Yes & Yes & Yes & Yes & Yes & Yes \\
\hline Log likelihood & -3846.64 & -2018.18 & -1639.67 & -3423.97 & -1882.34 & -1296.10 \\
\hline $\begin{array}{l}\mathrm{Chi}^{2} \text { (degree of } \\
\text { control) }\end{array}$ & $626.08(36)$ & $517.36(36)$ & $433.11(36)$ & $4 \mid 4.74(36)$ & $372.47(36)$ & $477.23(36) \mathrm{s}$ \\
\hline Obs. & 3488 & 1909 & 1579 & 3488 & 1909 & 1579 \\
\hline
\end{tabular}

HRM: human resource management.

All models control for individual and firm characteristics (results are available upon request).

$n_{\text {SMEs }}=448 ; n_{\text {small firms }}=296 ; n_{\text {medium-sized firms }}=152$.

Values in italic are standard errors.

We also estimate the model using ordered logistic regression for robustness check. Results are similar and available upon request.

We estimate the model using HR formality ${ }^{2}$ instead of HR formality. The coefficient of HR formality ${ }^{2}$ is also positive and significantly related to both indicators of firm performance in SMEs, small firms and medium-sized firms.

$*_{p}<0.01$.

from medium sized-firms, all at the $p<0.01$. These confirm the findings shown in Table 2. Hence, hypothesis 1 is accepted. We also find that the magnitude of the effect is greater in small organisations than that in medium-sized organisations.

To address hypotheses 2 and 3 regarding the relationship between formalised HR practices and firm performance within SMEs with different levels of employee commitment or job satisfaction, we estimate a multivariate model using an ordered probit regression model. We also control for a wide range of individual and firm characteristics. Our model also includes an interaction term between HR formality and employee commitment and/or job satisfaction in order to examine the moderating effect of work attitudes. Table 4 (see Panel A) presents the coefficient results for financial performance by firm size. For the overall sample, we find that the interaction effect between high employee commitment and HR formality is insignificant for financial performance of SMEs. This suggests that there is only a positive and direct association between formalised HR practices and firm performance, and that the relationship appears to be independent of whether or not employees are highly committed to the organisation. Hypothesis $2 \mathrm{a}$ is therefore not accepted. The coefficient for the interaction between formality and employee job satisfaction, however, is statistically significant and negatively related to financial performance in SMEs, at the $p<0.10$ level. Hence, hypothesis $3 \mathrm{a}$ is accepted. Table 4 (see Panel B) also shows the coefficient results for labour productivity by firm size. The results reveal that, regardless of firm size, the positive and direct link between formalised HR practices and labour productivity does not vary between groups with either high organisational commitment or high job satisfaction. Hypotheses $2 b$ and $3 b$ are therefore not accepted.

We also estimate separate models for small firms and medium-sized firms with high and low employee commitment or satisfaction. The first observation is that high employee commitment moderates the positive and direct relationship between formalised HR practices and financial performance in medium-sized firms (at the $p<0.05$ level), but not in small firms. Additionally, the 
Table 4. Ordered probit estimation of firm performance with high and low employee commitment or/ and job satisfaction.

\begin{tabular}{|c|c|c|c|c|c|c|}
\hline \multirow{2}{*}{$\begin{array}{l}\text { Firm performance } \\
\text { Firm size }\end{array}$} & \multicolumn{3}{|c|}{ Panel A: Financial performance } & \multicolumn{3}{|c|}{ Panel B: Labour productivity } \\
\hline & SMEs & Small firms & $\begin{array}{l}\text { Medium- } \\
\text { sized firms }\end{array}$ & SMEs & Small firms & $\begin{array}{l}\text { Medium- } \\
\text { sized firms }\end{array}$ \\
\hline $\begin{array}{l}\text { Ordered probit } \\
\text { regression }\end{array}$ & Coefficient & Coefficient & Coefficient & Coefficient & Coefficient & Coefficient \\
\hline \multirow[t]{2}{*}{ Formalised HR practices } & $1.169 * * *$ & $1.158 * * *$ & $1.749 * * *$ & $0.717^{* * * *}$ & $0.772 * * *$ & 0.495 \\
\hline & 0.214 & 0.284 & 0.431 & 0.219 & 0.288 & 0.455 \\
\hline \multirow{2}{*}{$\begin{array}{l}\text { Organisational } \\
\text { commitment }\end{array}$} & 0.251 & 0.106 & $0.922 * *$ & -0.139 & -0.195 & -0.097 \\
\hline & 0.182 & 0.218 & 0.417 & 0.188 & 0.221 & 0.440 \\
\hline \multirow{2}{*}{$\begin{array}{l}\text { Formality } \times \text { organisational } \\
\text { commitment }\end{array}$} & -0.121 & 0.076 & $-0.994 * *$ & 0.294 & 0.413 & 0.181 \\
\hline & 0.237 & 0.305 & 0.504 & 0.244 & 0.310 & 0.531 \\
\hline Controls & Yes & Yes & Yes & Yes & Yes & Yes \\
\hline Log likelihood & -3840.18 & -2015.10 & -1636.39 & -3421.71 & -1880.56 & -1295.79 \\
\hline $\mathrm{Chi}^{2}$ (degree of freedom) & $638.99(38)$ & $523.54(38)$ & $439.67(38)$ & $419.26(38)$ & $376.03(38)$ & $477.86(38)$ \\
\hline \multirow[t]{2}{*}{ Formalised HR practices } & $1.333 * * *$ & $1.588 * * *$ & $1.331 * * *$ & $0.984 * * *$ & $1.246 * * *$ & 0.376 \\
\hline & 0.177 & 0.234 & 0.353 & 0.181 & 0.237 & 0.373 \\
\hline \multirow[t]{2}{*}{ Job satisfaction } & $0.397^{* *}$ & $0.448^{* *}$ & 0.554 & 0.118 & 0.256 & -0.373 \\
\hline & 0.164 & 0.194 & 0.391 & 0.169 & 0.197 & $0.4 / 4$ \\
\hline \multirow{2}{*}{$\begin{array}{l}\text { Formality } \times \text { job } \\
\text { satisfaction }\end{array}$} & $-0.376 *$ & $-0.555^{* *}$ & -0.499 & -0.053 & -0.214 & 0.490 \\
\hline & 0.210 & 0.266 & 0.466 & 0.216 & 0.269 & 0.493 \\
\hline Controls & Yes & Yes & Yes & Yes & Yes & Yes \\
\hline Log likelihood & -3840.91 & -2015.40 & -1636.24 & -3422.03 & -1880.180 & -1295.450 \\
\hline $\mathrm{Chi}^{2}$ (degree of freedom) & $637.54(38)$ & $522.92(38)$ & $439.97(38)$ & $418.62(38)$ & $376.08(38)$ & $478.54(38)$ \\
\hline Obs. & 3488 & 1909 & 1579 & 3488 & 1909 & 1579 \\
\hline
\end{tabular}

HR: human resource.

All models control for a wide range of explanatory variables (results are available upon request).

Values in italic are standard errors.

We estimate the model using ordered logistic regression for robustness check. Results are similar and available upon request.

We also estimate the ordered probit regression, using the interaction between HR formality and continuous employee commitment and job satisfaction. Only the interaction between employee commitment and HR formality is found to be statistically significant.

$*_{p}<0.10 ; * * p<0.05 ; * * * p<0.01$.

coefficient for the interaction effect between formalised HR practices and high employee job satisfaction is statistically significant and negative in small firms (at the $p<0.05$ level), but not in medium-sized firms.

\section{Discussion}

Situated within the universalistic framework, SET and contingency theory, this study has examined the relationship between HR practices, employee attitudes (job satisfaction and organisational commitment) and firm performance in SMEs. First, we examined the direct relationship between formalised HR practices and firm performance in SMEs. The estimation results show that the HR formality index is positively and significantly linked to financial performance and labour productivity in the overall SME population, as well as in split samples of small and medium-sized firms. 
This is consistent with the cross-sectional analyses of Michie and Sheehan (2008) and Way (2002), and lends some prima facie support to the universalistic perspective of SHRM and notions that in terms of HR practices, 'more is better' (De Winne and Sels, 2013). Such perspectives suggest that there is a universally positive relationship between particular HR practices and firm performance, irrespective of business context and environment. However, these analysis presented seems to question earlier arguments in the literature which suggest that HR formality may be unnecessary or even detrimental (Saridakis et al., 2013).

Perhaps this is partly because management informality is a matter of degree, is unlikely to be static and may evolve over time (Edwards and Ram, 2010). Existing research has shown that in practice, informal and formal HR practices co-exist in small firms and the boundaries are not clear cut (Marlow et al., 2010; Sparrow, 2006). As firms grow, they may struggle to control the internal environment in the same way, and it may become increasingly impractical for senior leaders to manage workforce issues directly (Storey et al., 2010). A need to standardise, specialise and formalise management processes may thus emerge as organisations' attempt to manage a larger and more complex workforce (Daft, 1998; Marlow et al., 2010), and this 'formalisation' may be encouraged and potentially beneficial (Nguyen and Bryant, 2004; Patel and Cardon, 2010). Perhaps the key challenge for SMEs is to introduce an appropriate level of formalisation to manage effectively and improve firm performance while not damaging or disregarding the potential benefits of informality. As Ram et al. (2001) note, 'all firms combine formality and informality just as they combine control and consent ... the balance differs as conditions vary' (p. 859). However, capturing the benefits of both formality and informality - and achieving an appropriate balance between the two - is a dilemma that warrants further research (Bartram, 2005; Saridakis et al., 2013).

Second, we examined whether high organisational commitment, or high job satisfaction, moderated the relationship between formalised HR practices and firm performance (financial performance and labour productivity) in SMEs. Interestingly, the results of the estimations, including the interaction between HR formality and positive work attitudes, reveal that the positive relationship between formalised HR practices and SME financial performance is moderated by high job satisfaction, but not by organisational commitment. More specifically, for SMEs with high employee job satisfaction, the positive relationship between HRM and financial performance is actually weakened as formalisation increases. In other words, the development of a structured and highly formalised HRM system seems unnecessary in SMEs that already have a highly satisfied workforce. This suggests that small businesses can create a working environment that is consistent with the principles underlying the AMO framework through more informal mechanisms. In practice, this may be characterised by direct and fast channels of communication, a strong sense of team working and close social relations, high levels of involvement and participation, great discretion over the work, and a clear link between individual efforts and the aims of the organisation (Saridakis et al., 2013; Sels et al., 2006). It may also help to develop a reciprocal relationship in which the employer provides a supportive and favourable environment in exchange for loyalty and job satisfaction on the part of the employees (Rupp and Cropanzano, 2002). This finding lends some support to the arguments of the contingency theorists that the use of specific employment practices and its relationship with firm performance is contingent upon the particular organisational or environmental context.

However, no evidence of the moderating effect of organisational commitment/job satisfaction is found in the relationship between formalised HR practices and SME labour productivity. This suggests that the association does not vary between SMEs with high levels of positive work attitudes and those with low levels. Potentially, the employment systems contribute to improvements in aggregated labour productivity through other intervening routes, such as developing employee 
skills and abilities (i.e. their 'capability' for performance) (Cooke, 2001), and the use of technologies and methods of production. We propose that HRM activities that strive to improve the skills of human capital and to incentivise the use of skills may be viewed as more relevant to higher labour productivity (Katou and Budhwar, 2010). Sheehan (2014) suggests that the impact of training on performance has been investigated most frequently in the HRM-performance relationship literature in small firms, and a positive association with performance has repeatedly been identified (De Kok et al., 2002).

A further possible reason that the HRM-performance relationship in SMEs is independent of the level of organisational commitment $(\mathrm{H} 2 \mathrm{a}$ and $\mathrm{H} 3 \mathrm{a}$ ) but not job satisfaction may lie in the difference in their definitions and driving forces. Gumbang et al. (2010) argue that job satisfaction and organisational commitment are related, but distinguishable, attitudes. While the former is associated with the affective response to the immediate work environment, the latter is an affective response to the whole organisation (Chen, 2006). Arguably, high levels of employee job satisfaction are easier and quicker to attain as long as firms can provide a pleasant work environment for their employees, and subsequently improving employee job performance and productivity. In the small-business context, such preferable work conditions are often manifested in the informal HR practices and work mechanisms centred on recognition, responsibility and discretion at work, in other words the intrinsic aspects of job satisfaction (Herzberg, 1996). Yet, employee commitment, particularly affective commitment, is often concerned with the identification and internalisation base ${ }^{8}$ (Becker et al., 1996), the enjoyment of being a member of the organisation and a congruence between individual and organisational values and beliefs. Generally, organisational commitment is developed through the functions of the organisational culture and by creating the feeling of identity among the personnel and a competitive edge to help the members in the organisation to understand acceptable behaviour and social systems (Martins, 2000). As just one important managerial mechanism (other tools include strategic direction, goals, structure, decision-making and so forth), HR policy and practices alone may not be able to capture the whole nature of the organisational culture to foster commitment. This may help explain the insignificant role of organisational commitment on moderating the HRMperformance relationship. Hogg and Terry (2000) argue that committed employees possess a greater perception of shared interests with those of their organisation; they may gradually depersonalise and de-emphasise their self-interest in place of organisational interest and values, considering themselves as integral to the collective (Mael and Ashforth, 1992). Hence, organisational commitment is more deeply rooted, stable and enduring than the other types of job attitudes including job satisfaction (Tett and Meyer, 1993). Highly committed employees who share their goals are more willing to make an effort and wish to remain organisational members, and may not resent the formality introduced by their employers (Marsden et al., 2000). In short, our analysis highlights the complex nature of the connections between employee attitudes such as organisational commitment and job satisfaction. Given their centrality to debates concerning the links between HR policies/practices and organisational performance (Appelbaum et al., 2000; Huselid, 1995; Purcell et. al., 2003), there is a need for further research in this area.

Finally, when the overall SME WERS sample is split between small and medium-sized firms, the analyses reveal that organisational commitment moderates the positive association between formalised HR practices and financial performance in medium-sized firms, whereas with job satisfaction, this is the case in small firms only. Possibly, as firms grow, organisational commitment becomes more important as employees seek to identify with the organisation. Given an increasing distance between front-line employees and top management in larger firms, formality may be regarded as a signal that the values and beliefs of individuals are congruent with those of the 
organisation (Takeuchi et al., 2009). Our findings also confirm the well-known heterogeneity and diversity of small firms noted in the literature (Atkinson, 2008; Hurst and Pugsley, 2011). It is likely that there are a range of diverse forces shaping HRM and performance in small-businesses, and that the SME population may need to be separated between small and medium-sized firms in future HRM research.

\section{Implications and limitations}

Our findings have important implications for practice and research. For practice, and in contrast to the best practice view, we suggest that the appropriate choice of HR practices is likely to depend on specific organisational factors, and that the development of a successful HRM strategy should take these factors into account (Katou and Budhwar, 2006; Paauwe et al., 2013). In contrast to a number of studies that identify a positive and direct relationship between HR practices and firm performance (Messersmith and Wales, 2011; Nguyen and Bryant, 2004), as well as the popularity of the 'more is better' hypothesis (De Winne and Sels, 2013), we reveal that management formality is not always desirable, or essential, in SMEs. Rather, in organisations where levels of positive work attitudes such as job satisfaction are high within the context of informality and flexibility, introducing a more structured and formal approach to HRM might be undesirable. In such environments, greater formality may jeopardise the competitive advantage achieved with a context of informal practices and resultant employee satisfaction (Ciavarella, 2003; Edwards and Ram, 2010). On the other hand, our results suggest that in small firms with low organisational commitment or low job satisfaction, there may be scope to increase management formality in order to improve employee job performance and overall organisational performance. These management interventions may be aimed at creating a sense of substantive fairness and common interests, leading to positive employee work attitudes and ultimately better firm performance. In practice, identifying and achieving an appropriate balance of formality and informality might be challenging (Bartram, 2005; Saridakis et al., 2008).

To conclude, and reflecting many of the studies of large firms, our findings lend some prima facie support to the 'one size fits all' perspective in relation to HR and SME performance. However, we also highlight the need for a more contingent view when we introduce hypotheses $\mathrm{H} 2$ and $\mathrm{H} 3$, and consider the role of employee attitudes rather than HR systems. While at a macro-level the HRM-performance link may be true in both large and small firms (H1), both management formality and employee responses differ (Storey et al., 2010). Given the extensive research which suggests that HRM and employment relations are managed differently in small firms, our study suggests some complexity and a need for more nuanced and contingent framework of SHRM in small organisations (Marlow et al., 2010). In short, we underline the shortcomings of popular but simplistic 'best practice' notions of HRM and performance, and highlight the need to continue to unpack the 'black box'.

There are, of course, limitations to the analysis in this article that may merit further investigation. Using a cross-sectional dataset, our findings suggest an association between HR practices and firm performance, and future studies that use panel data and longitudinal research to examine the causality or reverse causality between two variables are strongly recommended (Razouk, 2011; Sheehan, 2014). Despite a clear negative relationship between management formality and employee attitudes, Storey et al. (2010) posit that management formality may be endogenous due to inappropriate recruitment processes, external pressures (e.g. trade unions) for reducing unfair dismissals and equal opportunities, or isomorphism. Similarly, some authors (Schneider et al., 2003) also suggest the possibility of endogeneity of employee 
attitudes, for example, organisational performance influences employee attitudes rather than the reverse. Finally, in-depth insights into the realities, processes and experiences of both formal and informal employment relations in small organisations may require qualitative investigations, especially if they are to capture the precise nature of the formal/informal boundaries (Saridakis et al., 2013).

To conclude, the nature of the employment relationship in small-businesses is distinctive and often characterised as informal and ad hoc, shaped in part by the context of 'smallness' and 'resource constraint'. Our findings suggest that the formalisation in employee management practices, normally prescribed for large firms, and which form the normative thrust of much mainstream HR thinking, may not always be appropriate in the SME context. The relationship between the use of formalised HRM practices and firm performance may be contingent on other contextual and organisational factors (and in this case firm size). This is manifested in employee emotional and behavioural responses. Further research is encouraged to investigate the potential intermediators in the HRM-performance nexus.

\section{Appendix I}

Table 5. Weighted averages of positive attitudes within SME population.

\begin{tabular}{|c|c|c|}
\hline \multirow[t]{2}{*}{ Employee work attitudes } & \multicolumn{2}{|l|}{ Firm size } \\
\hline & Small firms & Medium-sized firms \\
\hline \multicolumn{3}{|l|}{ Organisational commitment } \\
\hline I share many of the values of my organisation. & 3.882 & 3.726 \\
\hline I feel loyal to my organisation. & 4.186 & 3.972 \\
\hline I am proud to tell people who I work for. & 4.068 & 3.905 \\
\hline Overall score & 4.045 & 3.868 \\
\hline \multicolumn{3}{|l|}{ Job satisfaction } \\
\hline Satisfaction with sense of achievement & 4.019 & 3.926 \\
\hline Satisfaction with scope of using own initiative & $\overline{4.123}$ & $\overline{3.987}$ \\
\hline Satisfaction with influence over the job & 3.936 & 3.757 \\
\hline Satisfaction with training & 3.572 & 3.395 \\
\hline Satisfaction with amount of pay & $\overline{3.640}$ & $\overline{3.469}$ \\
\hline Satisfaction with job security & $3.25 \mathrm{I}$ & 2.910 \\
\hline Satisfaction with the work itself & 3.792 & 3.602 \\
\hline Satisfaction with involvement in decision-making & $\overline{3.648}$ & $\overline{3.389}$ \\
\hline Overall score & 3.748 & 3.554 \\
\hline Obs. & 1909 & 1579 \\
\hline
\end{tabular}

SME: small and medium-sized enterprise.

$n_{\text {SMEs }}=448 ; n_{\text {small firms }}=296 ; n_{\text {medium-sized firms }}=152$.

We tested whether the means of small and medium-sized firms are statistically different from each other. Bold and underlined values indicate where the difference was found to be statistically significant at $1 \%$ and $5 \%$ levels, respectively. The results are consistent with those reported in Storey et al.'s (2010) and Saridakis et al.'s (2013) research based on Workplace Employment Relations Study of 2004 (WERS2004). These authors also conduct the regression models, controlling for a wide range of demographic variables, to further confirm the conclusion from comparing weighted averages in different sizes of firms. Since this is not the focus of the present study, we did not elaborate the regression results here. 
Table 6. Weighted proportion of formality within SME population.

\begin{tabular}{|c|c|c|}
\hline \multirow[t]{2}{*}{ HR practices $($ yes $=I$ or no $=0$ ) } & \multicolumn{2}{|l|}{ Firm size } \\
\hline & Small firms & Medium-sized firms \\
\hline Presence of HR professional on the board & $37.2 \%$ & $66.1 \%$ \\
\hline Presence of a formal strategic plan? & $52.5 \%$ & $73.7 \%$ \\
\hline Accredited as an Investor in People? & $8.1 \%$ & $22.1 \%$ \\
\hline $\begin{array}{l}\text { Presence of a standard induction programme designed to } \\
\text { introduce new employees }\end{array}$ & $76.6 \%$ & $93.2 \%$ \\
\hline Any procedure for dealing with discipline and dismissals & $85.9 \%$ & $\mathbf{9 8 . 0} \%$ \\
\hline Presence of a formal written for equal opportunity. & $67.7 \%$ & $95.1 \%$ \\
\hline A formal procedure for dealing with individual grievance & $88.4 \%$ & $\mathbf{9 8 . 4 \%}$ \\
\hline The presence of any formal targets & $71.3 \%$ & $90.7 \%$ \\
\hline Presence of performance appraisal & $66.5 \%$ & $80.5 \%$ \\
\hline Presence of non-pay benefits & $\overline{67.0 \%}$ & $\overline{83.9 \%}$ \\
\hline Any meetings between managers and the whole workforce & $65.6 \%$ & $\mathbf{8 8 . 0} \%$ \\
\hline Presence of formal communication channels & $91.4 \%$ & $99.7 \%$ \\
\hline Overall score (means) & 0.648 & 0.825 \\
\hline Obs. & 1909 & 1579 \\
\hline
\end{tabular}

SME: small and medium-sized enterprise; HR: human resource.

$n_{\text {SMEs }}=448 ; n_{\text {small firms }}=296 ; n_{\text {medium-sized firms }}=152$.

We tested whether the proportion and means of small and medium-sized firms are statistically different from each other. Bold and underlined values indicate where the difference was found to be statistically significant at $1 \%$ and $5 \%$ levels, respectively.

The results are consistent with those reported in Storey et al.'s (2010) and Saridakis et al.'s (20I3) research based on Workplace Employment Relations Study of 2004 (WERS2004). These authors also conduct the regression models, controlling for a wide range of demographic variables, to further confirm the conclusion from comparing weighted proportions in different sizes of firms. Since this is not the focus of the present study, we did not elaborate the regression results here.

Table 7. Descriptive statistics of study and controlled variables (means and proportions, weighted estimates).

\begin{tabular}{lcc}
\hline Variables & Mean & SD \\
\hline Formalised HR practices & 0.717 & 0.014 \\
Job satisfaction & 3.672 & 0.024 \\
Organisational commitment & 3.976 & 0.027 \\
Age of the workplace (log) & 2.803 & 0.063 \\
Workplace performance & $\%$ & \\
Financial performance (base cat. = not above average) & & \\
Labour productivity (base cat. =not above average) & 49.2 & \\
Employee level & 56.9 & \\
Tenure $>$ I year (base cat. = tenure $<$ I year) & & \\
Permanent (base cat. = fixed terms or temporary) & 83.6 & \\
Union member (base cat. =non-union member) & 93.4 & 7.6 \\
Female (base cat. =male) & 47.7 & \\
Age, years (base cat. $=$ I6-2I years) & & \\
I6-2I & 7.2 & \\
22-29 & 18.5 & \\
\hline
\end{tabular}


Table 7. (Continued)

\begin{tabular}{|c|c|c|}
\hline Variables & Mean & SD \\
\hline $30-39$ & 23.4 & \\
\hline $40-49$ & 24.7 & \\
\hline $50-64+$ & 26.2 & \\
\hline \multicolumn{3}{|l|}{ Wage per week (base cat. $=£ 60-£ 100$ per week) } \\
\hline$£ 60-100$ & 8.6 & \\
\hline$£|0|-220$ & 14.6 & \\
\hline$£ 221-310$ & 17.8 & \\
\hline$£ 311-430$ & 21.0 & \\
\hline$£ 431-520$ & 13.0 & \\
\hline$£ 521-650$ & 9.7 & \\
\hline$£ 651-820$ & 6.4 & \\
\hline$£ 821-1050$ & 3.5 & \\
\hline$>£ 1050$ & 5.3 & \\
\hline \multicolumn{3}{|l|}{ Organisation level } \\
\hline Unionisation (base cat. $=$ no presence of trade union) & 18.3 & \\
\hline \multicolumn{3}{|l|}{ Industry (base cat. $=$ manufacturing) } \\
\hline Manufacturing & 15.3 & \\
\hline Utility & 0.2 & \\
\hline Construction & 7.1 & \\
\hline Wholesale and retail & 13.7 & \\
\hline Transportation and storage & 1.8 & \\
\hline Accommodation and food service & 8.6 & \\
\hline Information and communication & 6.3 & \\
\hline Financial and real estate activities & 8.9 & \\
\hline Professional, scientific and technical & 13.4 & \\
\hline Admin and support service & 3.4 & \\
\hline Public service (e.g. Health, Education) & 18.8 & \\
\hline Arts, entertainment and recreation & 2.4 & \\
\hline \multicolumn{3}{|l|}{ Competition $($ base cat. $=$ high $)$} \\
\hline High & 75.0 & \\
\hline Neutral & 15.3 & \\
\hline Low & 9.7 & \\
\hline \multicolumn{3}{|l|}{ Current state of market (base cat. $=$ turbulent) } \\
\hline Turbulent & 33.5 & \\
\hline Declining & 17.1 & \\
\hline Mature & 18.7 & \\
\hline Growing & 30.7 & \\
\hline $\begin{array}{l}\text { Adversely affected by the recent recession (base } \\
\text { cat. = no) }\end{array}$ & 88.8 & \\
\hline
\end{tabular}

SD: standard deviation; HR: human resource. $N=3488$ employees; 448 privately owned SMEs.

Means and standard errors are shown for continuous variables only.

\section{Funding}

The author(s) received no financial support for the research, authorship and/or publication of this article. 


\section{Notes}

1. The other two sections are the Employee Representative Questionnaire and Financial Performance Questionnaire.

2. Following Saridakis et al. (2013) and Storey et al. (2010), our study is mainly concerned with privately owned organisations. Also, after missing data are dropped, only privately owned organisations were left in the dataset.

3. The model is also estimated using a probit regression for robustness check. In this case, the dependent variable takes the value 1 if 'a lot better than average' or 'better than average' and 0 otherwise. The results, however, remain largely unchanged.

4. The overall organisational commitment and job satisfaction measures that we constructed have continuous form (ranging from 1 to 5). To re-construct them into binary variables, first, we grouped the observations in their near discrete values of 1 (strongly disagree), 2 (disagree), 3 (neither agree nor disagree), 4 (agree) or 5 (strongly agree). We used 3 as a cut-off point, taking the value of 1 if the observations are located in the categories of 4 or 5 (cf. high employee commitment or/and satisfaction), and 0 otherwise.

5. Here, we do not elaborate upon the regression results, which would be a repetition from Storey et al.'s (2010) work based on WERS2004. The $12 \mathrm{HR}$ practices are 'presence of a person mainly concerned with HR issues', 'existence of a formal strategic plan', 'accredited as an Investor in People', 'presence of a standard induction programme', 'procedure for dealing with discipline and dismissals', 'a formal written policy for an equal opportunity policy', 'a formal procedure for dealing with a grievance procedure', 'presence of a formal target', 'any performance appraisal', 'any non-payment benefits', 'any meetings between management and the whole workforce' and 'presence of any formal communication channels between management and employees'. Responses to these questions are all measured on a binary scale: 'yes' (1) or ' $n o$ ' (0). The regression results show that the level of use of HR practices (either individual or overall HR score) is positively related to firm size within SME population.

6. This approach minimises potential biases introduced by the sample selection and response process.

7. We also estimate the model for large firms for comparison. As expected, the results are consistent with the majority of prior HRM-performance studies carried out in large organisations (Huselid, 1995; Wright et al., 2005). We did not discuss these results in detail because they are not the main concern of the present study, but the results are available upon request.

8. The identification or affiliation-based commitment suggests that people adopt attitudes and behaviours in order to establish or maintain a satisfying relationship with another person or organisation. Internalisation or value congruence-based commitment suggests that people adopt attitudes and behaviours that are congruence with one's own values, which is identical to organisational values (Becker et al., 1996).

\section{References}

Allen MR and Wright R (2007) Strategic management and HRM. In: Boxall P, Purcell J and Wright P (eds) Oxford Handbook of Human Resource Management. Oxford: Oxford University Press, pp.88-107.

Allen MR, Ericksen J and Collins CJ (2013) Human resource management, employee exchange relationships, and performance in small business. Human Resource Management 52(2): 153-174.

Appelbaum E, Bailey T, Berg P, et al. (2000) Manufacturing Advantage: Why High-Performance Work Systems Pay off. Ithaca, NY: Cornell University Press.

Artz B (2008) The role of firm size and performance pay in determining employee job satisfaction brief: Firm size, performance pay and job satisfaction. Labour 22(2): 315-343.

Atkinson C (2008) An exploration of small firm psychological contracts. Work, Employment and Society 22(3): 447-465.

Bartram T (2005) Small firms, big ideas: The adoption of human resource management in Australian small firms. Asia Pacific Journal of Human Resources 43: 137-154.

Becker TE, Billings RS, Eveleth DM, et al. (1996) Foci and bases of employee commitment: Implications for job performance. Academy of Management Journal 39: 464-482.

Becker B and Gerhart B (1996) The impact of human resource management on organisational performance: Progress and prospects. Academy of Management Journal 39(4): 779-801. 
Becker BE and Huselid MA (2006) Strategic human resource management: Where do we go from here? Journal of Management 32: 898-925.

Blau PM (1964) Exchange and Power in Social Life. New York: Wiley.

Blyton P, Fleery E, Bacon N, et al. (2008) (eds) The Sage Handbook of Industrial Relations. London: SAGE.

Boselie P, Dietz G and Boon C (2005) Commonalities and contradictions in the HRM and performance research. Human Resource Management Journal 15(3): 67-94.

Boxall P and Purcell J (2011) Strategy and Human Resource Management (3rd edn). Basingstoke: Palgrave Macmillan.

Brown S, McHardy J, McNabb R, et al. (2010) Workplace performance, worker commitment, and loyalty. Journal of Economics and Management 20: 925-955.

Cassell C, Nadin S, Gray M, et al. (2002) Exploring human resource management practices in small and medium sized enterprises. Personnel Review 31(5/6): 671-693.

Chen CF (2006) Job satisfaction, organisational commitment, and flight attendants' turnover intentions: A note. Journal of Air Transport Management 2: 274-276.

Chuang W-JA and Huang A (2005) Relationship between strategic human resource management and firm performance: A contingency perspective. International Journal of Manpower 26(5): 434-449.

Ciavarella MA (2003) The adoption of high-involvement practices and processes in emergent and developing firms: A descriptive and prescriptive approach. Human Resource Management 43(4): 337-356.

Combs J, Liu Y, Hall A, et al. (2006) How much do high-performance work practices matter? A meta-analysis of their effects on organisational performance. Personnel Psychology 59: 501-528.

Conway E and Monks K (2009) Unravelling the complexities of high commitment: An employee-level analysis. Human Resource Management Journal 19: 140-158.

Cooke FL (2001) Human resource strategy to improve organizational performance: A route for firms in Britain? International Journal of Management Review 3(4): 321-339.

Cullinane N and Dundon T (2006) The psychological contract: A critical review. Industrial Journal of Management Reviews 8(2): 113-129.

Daft RL (1998) Essentials of Organisation Theory and Design. Cincinnati, OH: South-Western College Publishing.

De Clercq D and Belausteguigoitia Rius I (2007) Organisational commitment in Mexican small and mediumsized firms: The role of work status, organisational climate, and entrepreneurial orientation. Journal of Small Business Management 45: 467-490.

De Kok JMP, Uhlaner LM and Thurik AR (2002) Human Resource Management in Small and Medium-sized Firms: Strategic Study. Zoetermeer: EIM Business and Policy Research.

De Kok JMP (2003) Human resource management within small and medium-sized enterprises. Doctoral Dissertation, Erasmus University.

De Kok JMP and Uhlaner LM (2001) Organisation context and human resource management in the small firm. Small Business Economics 17: 273-291.

De Winne S and Sels L (2013) Progress and prospects for HRM-performance research in small and mediumsized business. In: Paauwe J, Guest D and Wright P (eds) HRM \& Performance: Achievements \& Challenges. Hoboken, NJ: Wiley, pp.173-197.

Deepchand K, Drever E, Gilby N, et al. (2013) Workplace Employment Relations Study (WERS) 2011/2012: Technical Report. London: National Centre for Social Research.

Delbridge R and Keenoy T (2011) Beyond managerialism. International Journal of Human Resource Management 21(5): 799-817.

Delery JE and Doty HD (1996) Modes of theorising in strategic human resource management: Tests of universalistic, contingency, and configurational performance predictions. Academy of Management Journal 39(4): 802-835.

Den Hartog DN and Verburg RM (2004) High performance work systems, organisational culture and firm performance. Human Resource Management Journal 14: 55-78.

Drummond I and Stone I (2007) Exploring the potential of high performance work systems in SMEs. Employee Relations 29(2): 192-207.

Edwards P and Ram M (2010) HRM in small firms: Respecting and regulating informality. In: Wilkinson A, Bacon N, Redman T, et al. (eds) The Sage Handbook of Human Resource Management. London: SAGE, pp. 524-540.

Ferguson KL and Reio TG (2010) Human resource management systems and firm performance. Journal of Management Development 29(5): 471-494. 
Fiorito J, Bozeman DP, Young A, et al. (2007) Organisational commitment, human resource practices, and organisational characteristics. Journal of Managerial Issues 19(2): 186-207.

Forth J and McNabb R (2008) Workplace performance: A comparison of subjective and objective measures in the 2004 workplace employment relations survey. Industrial Relations Journal 39: 104-123.

Forth J, Bewley H and Bryson A (2006) Small and Medium-Sized Enterprises: Findings from the 2004 Workplace Employment Relations Survey. London: Department of Trade and Industry.

Gould-Williams J (2007) HR practices, organisational climate and employee outcomes: Evaluation social exchange relationships in local government. International Journal of Human Resource Management 18(9): 1627-1647.

Gould-Williams J and Davis F (2005) Using social exchange theory to predict the effects of HRM practices on employee outcomes. Public Management Review 7(1): 1-24.

Guest D (2002) Human resource management, corporate performance and employee wellbeing: Building the worker into HRM. Journal of Industrial Relations 44(3): 335-358.

Guest D and Conway N (2011) The impact of HR practices, HR effectiveness and a 'strong HR system' on organisational outcomes: A stakeholder perspective. International Journal of Human Resource Management 22(8): 1686-1702.

Guest D, Namey E and Mitchell M (2013) Sampling. In: Guest D, Namey E and Mitchell M (eds) Collecting Qualitative Data: A Field Manual for Applied Research. Thousand Oaks, CA: SAGE, pp.41-47.

Guest DE (1999) Human resource management-the workers' verdict. Human Resource Management Journal 9(3): 5-25.

Guest DE (2011) Human resource and performance: Still searching for some answers. Human Resource Management Journal 21(1): 3-13.

Gumbang B, Suki MN and Suki MN (2010) Differences between job satisfaction, organisational commitment and gender. Labuan E-Journal of Muamalat and Society 4: 1-13.

Guzzo RA and Shea GP (1992) Group performance and intergroup relations in organisations. In: Dunnette MD and Hough LM (eds) Handbook of Industrial and Organizational Psychology. Palo Alto, CA: Consulting Psychologists Press, pp.269-313.

Harney B and Jordan C (2008) Unlocking the black box: Line managers and HRM-performance in a call centre context. International Journal of Productivity and Performance Management 57(4): 275-296.

Herzberg F (1996) Work and the Nature of Man. Cleveland, OH: World Publishing Company.

Hogg MA and Terry DJ (2000) Social identity and self-categorization processes in organizational contexts. Academy of Management Review 25: 121-140.

Hoque K and Bacon N (2006) The antecedents of training activity in British small and medium-sized enterprises. Work, Employment and Society 20: 531-552.

Hurst E and Pugsley BW (2011) Understanding small business heterogeneity. Working paper 17041. Cambridge, MA: National Bureau of Economic Research.

Huselid M (1995) The impact of human resource management practices on turnover, productivity, and corporate financial performance. Academy of Management Journal 38(3): 635-872.

Jack S, Hyman J and Osborne F (2006) Small entrepreneurial ventures culture, change and the impact on HRM: A critical review. Human Resource Management Review 16(4): 456-466.

Jiang K, Lepak DP, Hu J, et al. (2012) How does human resource management influence organisational outcomes? A meta-analytic investigation of mediating mechanism. Academy of Management Journal 55(6): 1264-1294.

Jiang K, Takeuchi R and Lepak DP (2013) Where do we go from here? New perspectives on the black box in strategic human resource management research. Journal of Management Studies 50(8): $1448-1480$.

Kaman V, McCarthy AM, Gulbro RD, et al. (2001) Bureaucratic and high commitment HRM in small service firms. Human Resource Planning 24(1): 33-44.

Katou AA and Budhwar P (2006) Human resource management systems on organizational performance: A test of mediating model in the Greek manufacturing context. International Journal of Human Resource Management 17(7): 1223-1253.

Katou AA and Budhwar PS (2010) Causal relationship between HRM policies and organisational performance: Evidence from the Greek manufacturing sector. European Management Journal 28(1): 25-39. 
Kaufman B (2010) SHRM theory in the post-Huselid era: Why it is fundamentally mis-specified. Industrial Relations 49(2): 296-313.

Kaufman BE (2015) Market competition, HRM, and firm performance: The conventional paradigm critiqued and reformulated. Human Resource Management Review 25(1): 107-125.

Kersley B, Aplin C, Forth J, et al. (2006) Inside the Workplace: Findings from the 2004 Workplace Employment Relations Survey. London: Routledge.

Kitching J and Marlow S (2013) HR practices and small firm growth: Balancing informality and formality. In: Saridakis G and Cooper CL (eds) How Can HR Drive Growth. Cheltenham: Edward Elgar Publishing Limited, pp.26-45.

Kuvaas B (2008) An exploration of how the employee-organisation relationship affects the linkage between perception of developmental human resource practices and employee outcomes. Journal of Management Studies 45: 1-25.

Legge K. (2004) Human Resource Management: Rhetorics and Realities. London: Palgrave Macmillan.

Lepak DP, Takeuchi R, Erhardt NL, et al. (2006) Emerging perspective on the relationship between HRM and performance. In: Burke RJ and Cooper CL (eds) The Human Resource Revolution: Why Putting People First Matters. Oxford: Elsevier, pp.31-54.

Locke EA (1976) The nature of causes of job satisfaction. In: Dunnette MD (ed.) Handbook of Industrial and Organisational Psychology. Chicago, IL: Rand McNally, pp.1297-1349.

McCartney C and Wilmott B (2009) Employee outlook: Job seeking in a recession. Quarterly Survey Report, Summer, 23 July 2009.

McClean E and Collins CJ (2011) High-commitment HR practices, employee effort, and firm performance: Investigating the effects of HR practices across employee groups within professional services firms. Human Resource Management 50: 341-363.

MacDermid S, Hertzog J, Kensinger K, et al. (2001) The role of organisational size and industry in job quality and work-family relationships. Journal of Family and Economic Issues 22(20): 191-216.

MacDuffie JP (1995) Human resource bundles and manufacturing performance: Organisational logic and flexible production systems in the world auto industry. Industrial and Labour Relations 48: 197-221.

Mael FA and Ashforth BE (1992) Alumni and their alma mater: A partial test of the reformulated model of organizational identification. Journal of Organizational Behavior 13: 103-123.

Marchington M, Carrol M and Boxall P (2003) Labour scarcity and the survival of small firms. Human Resource Management Journal 13: 5-22.

Marlow S (2005) Introduction. In: Marlow S, Patton D and Ram M (eds) Managing Labour in Small Firms. Abingdon: Routledge, pp.1-17.

Marlow S, Taylor S and Thompson A (2010) Informality and formality in medium-sized companies: Contestation and synchronisation. British Journal of Management 21: 954-966.

Marsden D, French S and Kobi K (2000) Why Does Performance Pay Demotivate? Financial Incentives versus Performance Appraisal. London: Centre for Economic Performance, London School of Economics and Political Science.

Martins EC (2000) The influence of organisational culture on creativity and innovation in a university library. MLnf Dissertation, University of South Africa.

Messersmith J and Wales J (2011) Entrepreneurial orientation and performance in young firms: The role of human resource management. International Small Business Journal. Epub ahead of print 16 November. DOI: $10.1177 / 0266242611416141$.

Michie J and Sheehan M (2008) Human resource management and corporate performance: Evidence from UK and US small firms. In: Barrett R and Mayson S (eds) International Handbook of Entrepreneurship and HRM. Cheltenham: Edward Elgar, pp.137-164.

Mowday RT, Porter LW and Steers RM (1982) Employee-Organisational Linkage: The Psychology of Commitment, Absenteeism and Turnover. New York: Academic Press.

Mowday RT, Steers RM and Porter LW (1979) The measurement of organisational commitment. Journal of Vocational Behaviour 14: 224-247.

Nadin S and Cassell C (2007) New deal for old? Exploring the psychological contract in a small firm environment. International Small Business Journal 25(4): 417-443. 
Nguyen TV and Bryant SE (2004) A study of the formality of human resource management practices in small and medium-size enterprises in Vietnam. International Small Business Journal 22(6): 595-618.

O'Fallon MJ and Butterfield KD (2005) A review of the empirical ethical decision-making literature: 1996-2003. Journal of Business Ethics 59: 375-413.

Paauwe J (2009) HRM and performance: Achievements, methodological issues and prospects. Journal of Management Studies 46(1): 129-142.

Paauwe J and Boselie P (2005) HRM and performance: What next? Human Resource Management Journal 15(4): 68-83.

Paauwe J, Guest D and Wright P (2013) HRM and Performance: Achievement and Challenge. Chichester: Wiley Press.

Patel PC and Cardon MS (2010) Adopting HRM practices and their effectiveness in small firms facing product-market competition. Human Resource Management 49(2): 265-290.

Pfeffer J (1998) The Human Equation: Building Profits by Putting People First. Boston, MA: Harvard Business School Press.

Purcell J, Kinnie N and Hutchinson S (2003) Understanding the People and Performance Link: Unlocking the Black Box. London: CIPD.

Purcell J (2014) Disengaging from engagement. Human Resource Management Journal 24(3): 241-254.

Ram M, Edwards P, Gilman M, et al. (2001) The dynamics of informality: Employment relations in small firms and the effects of regulatory change. Work Employment and Society 15: 845-861.

Razouk A (2011) High-performance work systems and performance of French small- and medium-sized enterprises: Examining causal order. International Journal of Human Resource Management 22(2): 311-330.

Rowden RW (2002) High performance and human resource characteristics of successful small manufacturing and processing companies. Leadership \& Organisation Development Journal 23(2): 79-83.

Rupp DE and Cropanzano R (2002) The mediating effects of social exchange relationships in predicting workplace outcomes from multifoci organisational justice. Organisational Behaviour and Human Decision Processes 89: 925-946.

Saridakis G, Sen-Gupta S, Edwards P, et al. (2008) The impact of enterprise size on employment tribunal incidence and outcomes: Evidences from Britain'. British Journal of Industrial Relations 46: 469-499.

Saridakis G, Torres RM and Johnstone S (2013) Do human resource practices enhance organisational commitment in SMEs with low employee satisfaction? British Journal of Management 24(3): 445-458.

Savaneviciene A and Stankeviciute Z (2012) Human resource management and performance: From practices towards sustainable competitive advantage. In: Guadra-Montiel H (ed.) Globalisation - Education and Management Agendas. Rijeka: InTech, pp.179-206.

Schneider B, Hanges PJ, Smith DB, et al. (2003) Which comes first: Employee attitude or organizational financial and market performance. Journal of Applied Psychology 88: 836-851.

Searle R, Den Hartog DN, Weibel A, et al. (2011) Trust in the employer: The role of high-involvement work practices and procedural justice in European organisations. International Journal of Human Resource Management 22(5): 1069-1092.

Sels L, De Winne S, Delmotte J, et al. (2006) Linking HRM and small business performance: An examination of the impact of HRM intensity on the productivity and financial performance of small business. Small Business Economics 26: 83-101.

Sheehan M (2014) Human resource management and performance: Evidence from small and medium-sized firms. International Small Business Journal 32(5): 545-570.

Singh M and Vohra N (2009) Level of formalisation of human resource management in small and medium enterprises in India. Journal of Entrepreneurship 18(1): 95-116.

Snape E and Redman T (2010) HRM practices, organisational citizenship behaviour, and performance: A multi-level analysis. Journal of Management Studies 47: 1119-1247.

Sparrow S (2006) We don't need HR. Personnel Today, 14 March. Available at: http://www.personneltoday. com/Articles/14/03/2006/34392/quotWe-don39t-need-HRquot.htm (accessed 22 April 2013).

Stock JH and Watson MW (2007) Introduction to Econometrics (2nd edn). Boston, MA: Pearson - AddisonWesley.

Storey DJ (2004) Exploring the link, among small firms, between management training and firm performance: A comparison between the UK and other OECD countries. International Journal of Human Resource Management 15(1): 112-130. 
Storey DJ, Saridakis G, Sen-Gupta S, et al. (2010) Linking HR formality with employee job quality: The role of firm and workplace size. Human Resource Management 49(2): 305-329.

Subramony M (2009) A meta-analytic investigation of the relationship between HRM bundles and firm performance. Human Resource Management 48: 745-768.

Swailes S (2002) Organizational commitment: A critique of the construct and measures. International Journal of Management Review 4(2): 155-178.

Takeuchi R, Chen G and Lepak DP (2009) Through the looking glass of a social system. Cross-sectional effects of high-performance work systems on employees' attitudes. Personnel Psychology 62(1): 1-29.

Tett RP and Meyer JP (1993) Job satisfaction, organisational commitment, turnover intention, and turnover: Path analysis based on meta-analytical findings. Personal Psychology 46: 259-293.

Thompson P and Harley B (2007) HRM and the worker: Labour process perspectives. In: Boxall P, Purcell $\mathrm{J}$ and Wright P (eds) The Oxford International Handbook of Human Resource Management. Oxford: Oxford University Press, pp.147-165.

Truss C, Shantz A, Soane E, et al. (2013) Employee engagement, organisational performance and individual well-being: Exploring the evidence, developing the theory. International Journal of Human Resource Management 24(14): 2657-2669.

Tsai CJ, Sen-Gupta S and Edwards P (2007) When and why is small beautiful? The experience of work in the small firm. Human Relations 60(12): 1779-1808.

Valentine S, Godkin L, Fleischman GM, et al. (2011) Corporate ethical values, group creativity, job satisfaction and turnover intention: The impact of work context on work responses. Journal of Business Ethics 98: 353-372.

Van Knippenberg D and Sleebos E (2006) Organisational identification versus organisational commitment: Self-definition, social exchange and job attitudes. Journal of Organisational Behavior 27(5): 571-584.

Van Wanrooy B, Bewley H, Bryson A, et al. (2013) The 2011 Workplace Employment Relations Study: First Findings. London: Department for Business, Innovation and Skills.

Wall TD and Wood SJ (2005) The romance of human resource management and business performance, and the case for big science. Human Relations 58(4): 429-462.

Wall TD, Michie J, Patterson M, et al. (2004) On the validity of subjective measures of company financial performance. Personnel Psychology 57: 95-118.

Wapshott R and Mallett O (2015) Managing Human Resources in Small and Medium-Sized Enterprises: Entrepreneurship and the Employment Relationship. London: Routledge.

Way SA (2002) High performance work systems and intermediate indicators of firm performance within the US small business sector. Journal of Management 28(6): 765-785.

Westhead P and Storey DJ (1996) Management training and small firm performance: Why is the link so weak? International Small Business Journal 14(4): 13-24.

Wright PM, Gardner T, Moyniham LM, et al. (2005) The HR performance relationship: Examining causal direction. Personnel Psychology 58(2): 409-446.

Wright P and Nishii LH (2013) Strategic HRM and organisational behaviour: Integrating multiple levels of analysis. In: Paauwe J, Guest D and Wright P (eds) HRM and Performance: Achievement and Challenges. Chichester: Wiley Press, pp.97-110.

\section{Author biographies}

Yanqing Lai has recently defended her PhD thesis. Her project was carried out at Kingston University Business School investigating "Employee Relations in SMEs". She is currently a research assistant at Edinburgh Napier University.

George Saridakis is Professor of Small Business and Entrepreneurship at Kingston University Business School and Honorary Professor at the University of the West Indies.

Stewart Johnstone is Senior Lecturer in Human Resource Management at Newcastle University Business School, Newcastle University. 